\title{
Komunitas Fitoplankton dan Konsentrasi Nutrien di Waduk Jatigede
}

\section{(Phytoplankton Community and Nutrient Concentration in Jatigede Reservoir)}

\author{
Randi Fitriadi ${ }^{1 *}$, Niken Tunjung Murti Pratiwi ${ }^{2}$, Rahmat Kurnia ${ }^{2}$ \\ (Diterima Agustus 2020/Disetujui Januari 2021)
}

\begin{abstract}
ABSTRAK
Waduk Jatigede merupakan salah satu waduk baru di Provinsi Jawa Barat. Informasi mengenai fitoplankton dan nutrien sangat sedikit. Kajian ini dilakukan dengan tujuan untuk menganalisis hubungan antara fitoplankton dengan nutrien di waduk tersebut. Penelitian dilakukan pada musim kemarau pada periode September-Oktrober 2018. Parameter yang dianalisis adalah kelimpahan fitoplankton, indeks diversitas dan dormansi, ortofosfat, nitrat, nitrit, dan amonium. Pembagian zonasi waduk dilakukan menggunakan analisis klaster. Hubungan fitoplankton dan nutrien dianalisis menggunakan analisis komponen utama dan korelasi Pearson. Fitoplankton di Waduk Jatigede terdiri atas kelas Bacillariophyceae, Chlorophyceae, Cyanophyceae, Dinophyceae, dan Euglenophyceae dengan kisaran kelimpahan 20.333-25.308 sel/L. Konsentrasi ortofosfat berkisar antara 0,0055-0,0082 mg/L. Konsentrasi nitrat

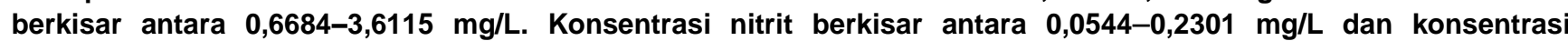
ammonium berkisar antara 0,00538-0,2460 mg/L. Kelas fitoplankton yang memiliki hubungan erat dengan nutrien adalah Cyanophyceae dan Dinophyceae, tertutama dengan orthofosfat, nitrat, nitrit, dan ammonium $(r>0,78)$.
\end{abstract}

Kata kunci: Cyanophyceae, orthofosfat, nitrat, nitrit

\section{ABSTRACT}

Jatigede reservoir is a new reservoir in West Java Province. There is not much information about phytoplankton and nutrients in this reservoir. The aim of the research was to study the relationship between phytoplankton community and nutrient in the reservoir. The research was conducted during the dry season, from September to October 2018. Analyzed parameters were phytoplankton abundance, diversity and dominance index, orthophosphate, nitrite, nitrate, and ammonium. Reservoir zonation was divided by cluster analysis. The relationship between phytoplankton and nutrients was analyzed by principal component analysis and Pearson's correlation test. Phytoplankton in Jatigede Reservoir consisted of Bacillariophyceae, Chlorophyceae, Cyanophycea, Dinophyceae, and Euglenophyceae within 20333-25308 cell/L. Nitrate concentration ranged within $0.6684-3.6115 \mathrm{mg} / \mathrm{L}$. Nitrite concentration ranged between $0.0544-0.2301 \mathrm{mg} / \mathrm{L}$ and ammonium ranged within $0.00538-0.2460 \mathrm{mg} / \mathrm{L}$. The strongest correlation between phytoplankton and nutrients were shown by Cyanophyceae and Dinophyceae, especially with the concentration of orthophosphate, nitrate, nitrite, and ammonium $(r>0,78)$.

Keywords: Cyanophyceae, orthophosphate, nitrate, nitrite

\section{PENDAHULUAN}

Waduk Jatigede merupakan waduk yang terletak di Kabupaten Sumedang, Provinsi Jawa Barat dengan luas 4.122 ha dan volume 1.063 juta $\mathrm{m}^{3}$, serta kedalaman rata-rata $25,8 \mathrm{~m}$ (Satuan Kerja Non Vertikal Waduk Jatigede dalam Warsa 2016). Waduk Jatigede dibangun pada tahun 2008 yang dimanfaatkan untuk sumber irigasi, bahan baku air minum, PLTA, pariwisata, dan perikanan. Warsa (2016) melaporkan bahwa kondisi perairan Waduk Jatigede sebelum

1 Sekolah Pascasarjana, Program Studi Pengelolaan Sumberdaya Perairan, Institut Pertanian Bogor, Kampus IPB Darmaga, Bogor 16680

2 Departemen Manajemen Sumberdaya Perairan, Fakultas Perikanan dan IImu Kelautan, Institut Pertanian Bogor, Kampus IPB Darmaga, Bogor 16680

* Penulis Korespondensi: Email: randifitriadi.rf@gmail.com penggenangan sempurna tergolong baik, namun berpotensi mengalami eutrofikasi.

Fitoplankton merupakan produsen utama di perairan tawar yang menyokong keberlangsungan kehidupan organisme lainnya. Sebagai penyokong kehidupan akuatik, fitoplankton dapat memberikan informasi mengenai kondisi lingkungan (McCormick \& Cairns 1994; Singh et al. 2013). Fitoplankton juga dapat menjadi alat monitoring atas perubahan lingkungan (Abubakar \& Abullahi 2015). Perubahan lingkungan diikuti oleh perubahan struktur komunitas fitoplankton, seperti diversitasnya. Perairan yang tidak tercemar ditandai dengan diversitas yang tinggi dan tidak terdapat dominansi oleh satu spesies (Thakur et al. 2013; Singh et al. 2013).

Struktur komunitas fitoplankton dipengaruhi oleh keberadaan nutrien di perairan. Nutrien merupakan parameter yang dibutuhkan untuk memprediksi jumlah spesies yang dibatasi oleh nutrien yang sama (Tillman 
1982). Kompetisi dalam pemanfaatan nutrien terjadi jika rasio nutrien optimal pada spesies tertentu dan menimbulkan kejadian dominansi oleh spesies tersebut. Rhee \& Gotham (1980) juga menyatakan bahwa nilai nutrien akan sejalan dengan organisme yang ada di perairan karena terdapat dominansi pada saat rasio $\mathrm{N}: \mathrm{P}$ optimum bagi organisme tertentu.

Sebagai salah satu waduk yang baru di Jawa Barat, informasi mengenai konsentrasi nutrien dan fitoplankton di waduk tersebut masih terbatas. Hubungan fitoplankton dan nutrien dapat dijadikan dasar dalam pengelolaan Waduk Jatigede, mengingat nutrien dan fitoplankton dapat menggambarkan kondisi perairan. Kajian ini bertujuan untuk menganalisis hubungan antara keberadaan fitoplankton dengan nutrien.

\section{METODE PENELITIAN}

\section{Waktu Penelitian}

Penelitian ini dilakukan di Waduk Jatigede, Kabupaten Sumedang, Provinsi Jawa Barat pada JuliAgustus 2018 dengan 6 kali pengambilan contoh. Pengambilan sampel fitoplankton menggunakan Plankton net (mesh size $35 \mu \mathrm{m}$ ) dan botol sampel untuk wadah hasil pengambilan sampel. Sampel fitoplankton diambil pada kedalaman $2 \mathrm{~m}$ dan diawetkan menggunakan larutan formalin. Sampel fosfat, nitrit, nitrat, dan amonium diawetkan menggunakan larutan $\mathrm{H}_{2} \mathrm{SO}_{4}$. Semua sampel tersebut dimasukkan ke dalam coolbox dan dibawa untuk dianalisis di laboratorium.
Lokasi pengambilan contoh dibagi menjadi 9 titik yang mewakili bagian-bagian waduk (Gambar 1).

\section{Analisis Laboratorium}

Parameter nutrien yang dianalisis di laboratorium adalah ortofosfat, nitrat, nitrit, dan amonium menggunakan metode APHA (2012). Pengukuran kualitas air dilakukan sebanyak 6 kali. Analisis Fitoplankton menggunakan metode pencacahan (APHA 2012) dan identifikasi menggunakan buku identifikasi Mizuno (1979).

\section{Analisis Data}

Data fitoplankton dianalisis menggunakan indeks diversitas Shannon-Wiener dan indeks dominansi Simpson (Krebs 2014). Pengelompokan stasiun penelitian dianalisis menggunakan analisis klaster (Legendre \& Legendre 1998). Korelasi fitoplankton dianalisis menggunakan analisis korelasi Pearson dan analisis komponen utama menggunakan korelasi antarvariabel (Legendre \& Legendre 1998).

\section{HASIL DAN PEMBAHASAN}

\section{Zonasi Waduk Jatigede}

Data contoh air dianalisis terlebih dahulu menggunakan analisis klaster. Hal ini bertujuan untuk mengobservasi zonasi spasial Waduk Jatigede. Parameter yang digunakan dalam analisis ini adalah ortofosfat, nitrat, nitrit, amonium, $\mathrm{DO}, \mathrm{pH}$, dan suhu. Hasil analisis menunjukkan bahwa Waduk Jatigede

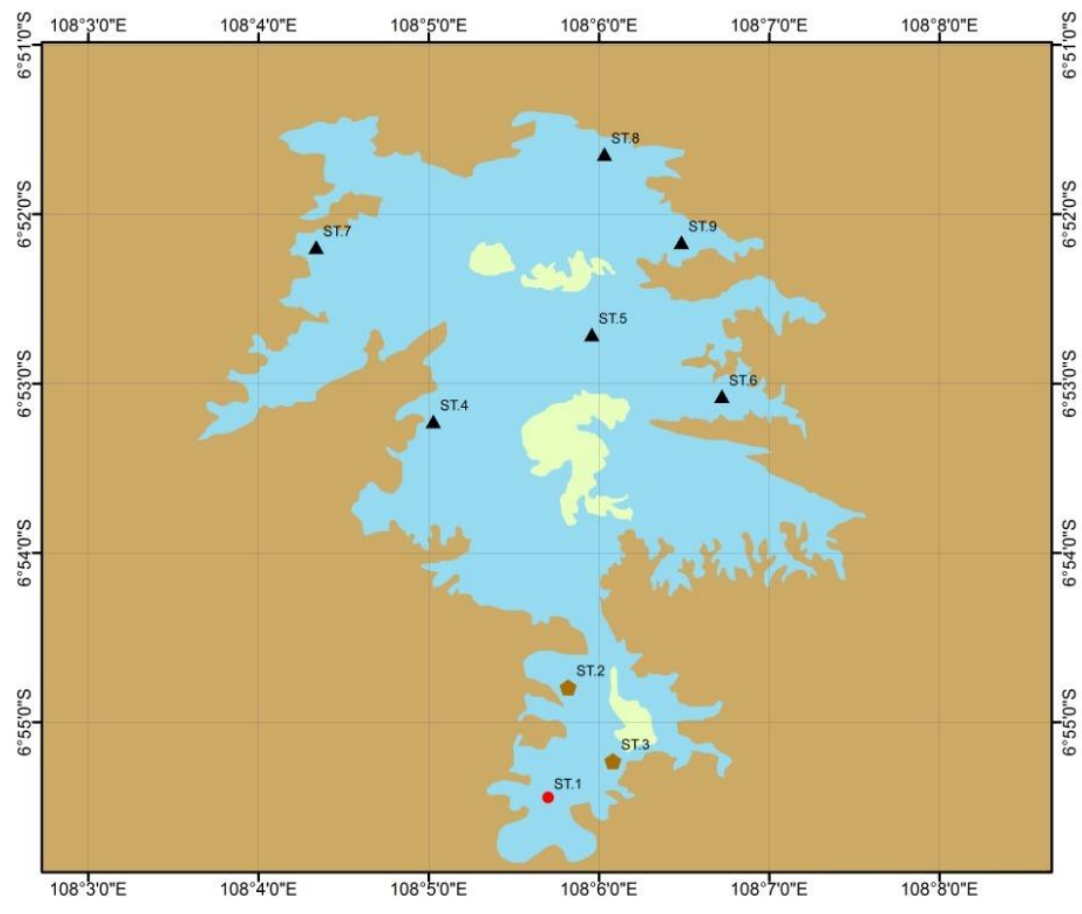

Gambar 1 Stasiun pengambilan contoh penelitian di Waduk Jatigede, Jawa Barat (ST1-ST9).

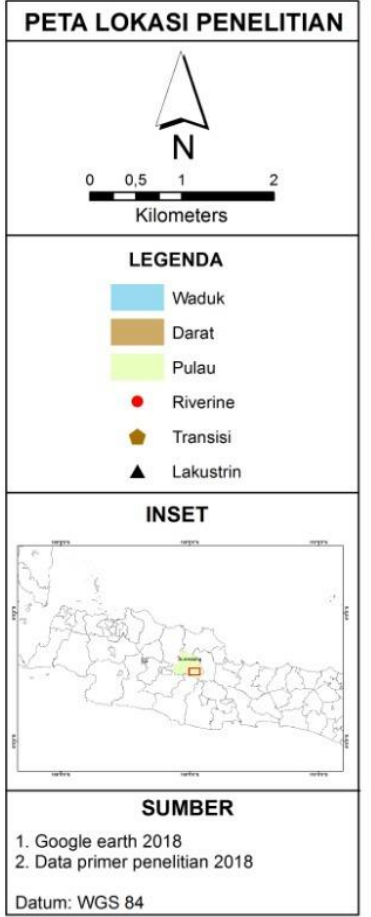


memilki 3 klaster zonasi spasial, yaitu riverin (ST1), transisi (ST2 dan ST3), dan Lakustrin (ST4-ST9) (Gambar 2).

Waduk Jatigede terbagi menjadi zona riverin, transisi, dan lakustrin berdasarkan analisis klaster. Zona riverin merupakan bagian waduk yang masih dipengaruhi oleh sungai. Riverin memiliki karakteristik yang tinggi nutrien dan paling subur. Zona selanjutnya merupakan zona transisi yang terdiri atas Stasiun 2 dan 3. Soares et. al (2008) menyatakan bahwa zona transisi memiliki nutrien yang lebih rendah dibandingkan dengan zona riverin. Konsentrasi fosfat Waduk Funil dan Lajes Brazil berkisar antara 0,4-12,3 $\mu \mathrm{M}$ di zona riverin dan $0,1-3,2 \mu \mathrm{M}$ di zona transisi. Tren tersebut sesuai dengan zonasi di Waduk Jatigede dengan konsentrasi orthofosfat di zona riverin adalah 0,0082 $\mathrm{mg} / \mathrm{L}$ dan di zona transisi adalah 0,0064 mg/L.
Zona terakhir adalah bagian lakustrin dengan konsentrasi terendah. Soares et al. (2008) menyatakan bahwa Waduk Funnil dan Waduk Lajes di Brazil terbagi menjadi 3 zonasi spasial berdasarkan parameter kualitas airnya.

\section{Komunitas fitoplankton}

Rata-rata kelimpahan fitoplankton selama penelitian adalah 20.333-25.308 sel/L. Kelimpahan tertinggi terdapat pada bagian riverin dan kelimpahan terendah di bagian lakustrin. Kelimpahan fitoplankton menurun dari bagian riverin ke transisi hingga lakustrin (Gambar 3).

Komposisi fitoplankton di Waduk Jatigede terdiri atas kelas Bacillariophyceae, Chlorophyceae, Cyanophyceae, Dinophyceae, dan Euglenophyceae. Kelas fitoplankton tersebut memiliki proporsi yang

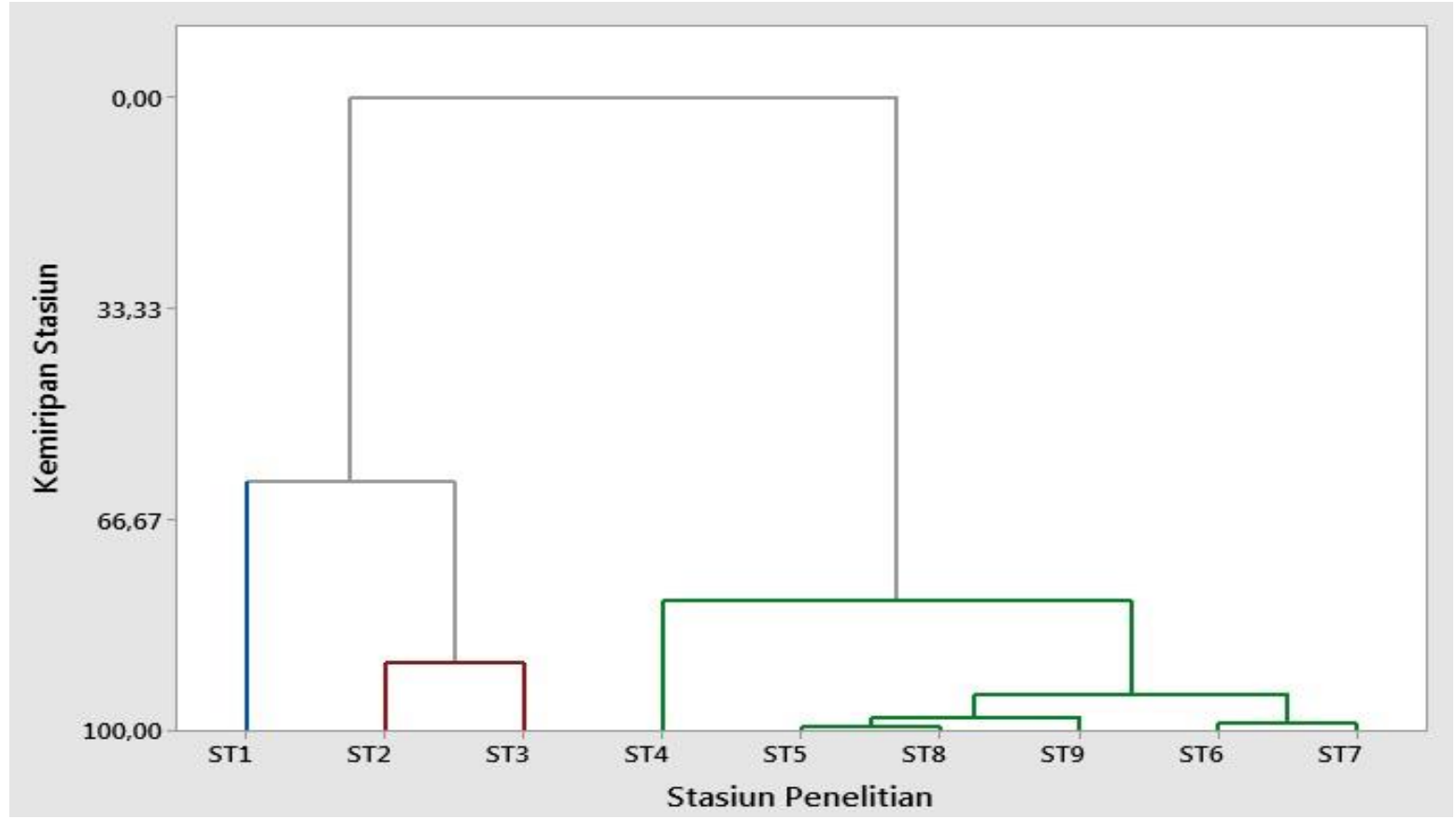

Gambar 2 Kluster zonasi spasial stasiun pengamatan di Waduk Jatigede, Jawa Barat berdasarkan parameter kimia (kadar ortofosfat, nitrat, nitrit, dan ammonium) serta parameter fisik (DP, $\mathrm{pH}$, dan suhu).

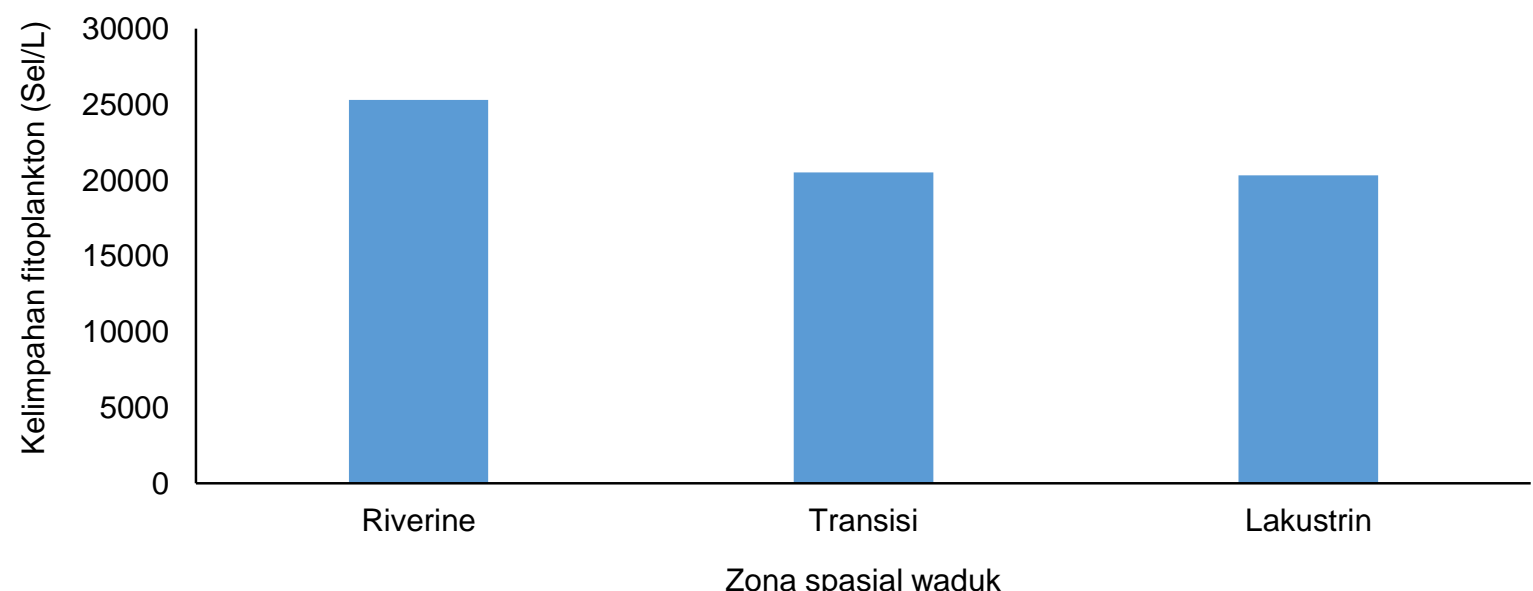

Gambar 3 Kelimpahan plankton di tiga zona spasial, yaitu riverin (ST1), transisi (ST2 dan ST3), dan lakustrin (ST4-ST9) Waduk Jatigede, Jawa Barat. 
berbeda pada setiap bagian waduk. Cyanophyceae merupakan kelas fitoplankton dengan proporsi tertinggi di bagian riverin dan lakustrin, namun proporsinya menurun pada bagian lakustrin. Proporsi fitoplankton terbesar pada bagian lakustrin adalah fitoplankton dari kelas Chlorophyceae. Proporsi terendah pada setiap bagian waduk adalah kelas Euglenophyceae (Gambar 4).

Diversitas fitoplankton pada penelitian ini diukur melalui indeks diversitas Shannon Wiener dan dominansi. Indeks diversitas tertinggi berada di bagian riverin dan terendah di bagian lakustrin. Nilai indeks diversitas memiliki tren yang menurun dari riverin, transisi, dan lakustrin. Indeks dominansi memiliki tren yang berbeda dari indeks diversitas. Nilai indeks dominansi meningkat dari bagian riverin ke lakustrin (Tabel 1).

\section{Kualitas Air dan Nutrien}

Nutrien yang diamati pada penelitian ini adalah nutrien yang termanfaatkan oleh fitoplankton, seperti ortofosfat, nitrat, nitrit, dan amonium. Ortofosfat merupakan fosfor yang terlarut di dalam perairan. Nilai ortofosfat di perairan berkisar antara 0,0055-0,0082 $\mathrm{mg} / \mathrm{L}$ (Tabel 2).

Waduk Jatigede memiliki konsentrasi ortofosfat yang rendah. Menurut OECD (1982) dalam Pratiwi et al. (2013), perairan dengan total fosfat $\leq 0,079 \mathrm{mg} / \mathrm{L}$ merupakan perairan oligotrof dan total fosfat berkisar 0,008-0,11 $\mathrm{mg} / \mathrm{L}$ merupakan perairan oligotrofmesotrof. Konsentrasi ortofosfat cenderung menurun dari zona riverin menuju lakustrin. Nilai ortofosfat yang tinggi di zona riverin juga dinyatakan oleh Jiao et al. (2018) bahwa bagian danau yang masih dipengaruhi oleh sungai merupakan zona yang memiliki konsentrasi ortofosfat yang tinggi di Danau Chauchu, China. Steinman et al. (2009) menyatakan bahwa fosfor masuk ke dalam perairan melalui runoff, masukan sungai, dan masukan dari sedimen. BPS Kabupaten Sumedang pada tahun 2019 menyatakan bahwa wilayah Waduk Jatigede tidak mengalami hujan ketika penelitian berlangsung selama musim kemarau dan tidak adanya hujan selama penelitian. Menurut BPS Kabupaten Sumedang (2019), curah hujan di Kecamatan Jatigede adalah $0 \mathrm{~mm}$ dan hari hujan adalah 0 hari. Hal ini diduga menyebabkan tidak adanya masukan fosfat yang berasal dari runoff daratan di sekitar waduk.

Konsentrasi nitrat di Waduk Jatigede berkisar antara 0,6684-3,6115 mg/L. Bagian riverin merupakan bagian dengan nitrat tertinggi dan konsentrasinya menurun sampai ke bagian lakustrin. Konsentrasi nitrit di Waduk Jatigede berkisar antara 0,0544-0,2301 $\mathrm{mg} / \mathrm{L}$. Nilai nitrit tertinggi berada pada bagian transisi dan terendah pada bagian lakustrin. Konsentrasi amonium di Waduk Jatigede berkisar antara 0,0538$0,2460 \mathrm{mg} / \mathrm{L}$. Konsentrasi tertinggi berada pada bagian riverin dan yang terendah pada bagian lakustrin (Tabel 2).

Konsentrasi nitrat selama penelitian berkisar antara 0,6684-3,6115 mg/L. Keberadaan nitrat di Waduk Jatigede tergolong lebih tinggi dibandingkan dengan Waduk Jatiluhur dengan kisaran konsentrasi 0,05$0,636 \mathrm{mg} / \mathrm{L}$ (Kusumaningtyas 2010). Konsentrasi nitrat

Tabel 4 Indeks diversitas dan dominansi fitoplankton di Waduk Jatigede

\begin{tabular}{lcc}
\hline \multicolumn{1}{c}{ Bagian waduk } & Diversitas & Dominansi \\
\hline Riverin & 2,069 & 0,193 \\
Transisi & 1,992 & 0,195 \\
Lakustrin & 1,734 & 0,259 \\
\hline
\end{tabular}

Tabel 5 Keberadaan konsentrasi nutrien di bagian Waduk Jatigede

\begin{tabular}{lcccc}
\hline $\begin{array}{c}\text { Parameter } \\
\text { nutrien }\end{array}$ & $\mathrm{PO} 4$ & $\mathrm{NO} 3$ & $\mathrm{NO} 2$ & $\mathrm{NH} 4$ \\
\hline Riverine & 0,008 & 3,612 & 0,204 & 0,246 \\
Transisi & 0,006 & 2,528 & 0,230 & 0,140 \\
Lakustrin & 0,006 & 0,668 & 0,054 & 0,054 \\
\hline
\end{tabular}

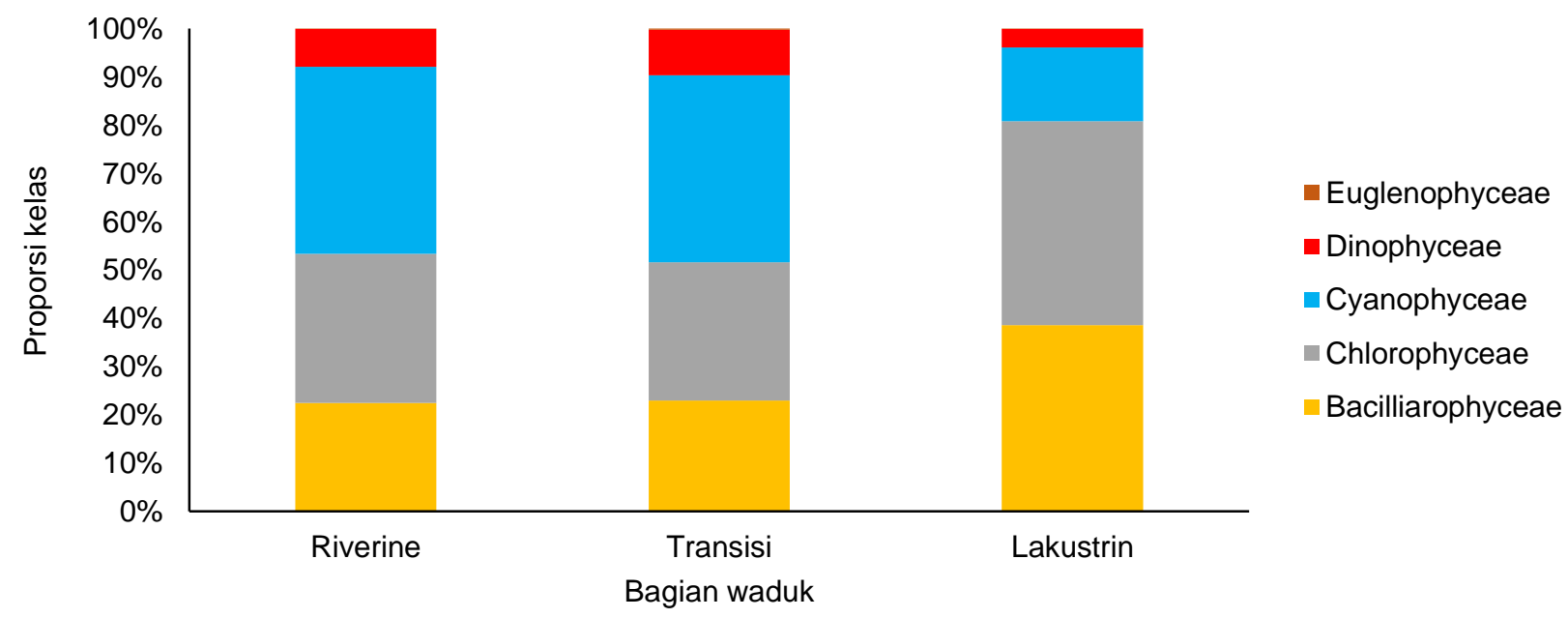

Gambar 4 Komposisi fitoplankton di tiga zona spasial, yaitu riverin (ST1), transisi (ST2 dan ST3), dan lakustrin (ST4-ST9) Waduk Jatigede, Jawa Barat. 
yang tinggi diduga karena laju oksigen terlarut dan $\mathrm{pH}$ yang mendukung nitrifikasi, namun juga masukan dari Sungai Cimanuk yang tinggi. Hal ini terlihat dari tren konsentrasi nitrat yang tinggi di bagian riverin dan menurun sampai ke bagian lakustrin. Konsentrasi tertinggi nitrit di Waduk Jatigede berada pada zona transisi. Zona transisi memiliki $\mathrm{pH}$ tertinggi sehingga menyebabkan nilai nitrit menjadi tinggi. Le (2018) menyatakan bahwa nitrit akan meningkat seiring dengan peningkatan nilai $\mathrm{pH}$. Nilai $\mathrm{pH}$ berhubungan dengan proses nitrifikasi yang terjadi di perairan di mana amonium teroksidasi menjadi nitrit. Zona lakustrin memiliki nitrat yang rendah walaupun $\mathrm{pH}$ tinggi dikarenakan volume air di bagian lakustrin lebih tinggi dibandingkan dengan di bagian transisi. Pada kondisi oksigen yang rendah dapat mendorong proses denitrifikasi dari nitrat dan nitrit menjadi amonium dan amonia sehingga amonium cukup melimpah. Pada penelitian ini, oksigen berkisar antara 7,210-7,646 $\mathrm{mg} / \mathrm{L}$.

Pengukuran temperatur di Waduk Jatigede dilakukan pada siang hari. Temperatur selama penelitian berkisar antara $26,54-26,59^{\circ} \mathrm{C}$. Bagian lakustrin memiliki temperatur yang paling tinggi di antara bagian waduk yang lainnya. Oksigen terlarut berkisar antara 7,21-7,65 mg/L. Konsentrasi oksigen terlarut yang tertinggi terdapat pada bagian lakustrin dan terendah pada bagian riverin. Nilai $\mathrm{pH}$ berkisar antara 7,35-7,51, nilai $\mathrm{pH}$ di bagian lakustrin lebih tinggi daripada di bagian riverin dan transisi (Tabel 3).

\section{Hubungan Fitoplankton dan Nutrien}

Hubungan fitoplankton dan kualitas air ditunjukkan dengan hasil analisis korelasi Pearson. Bacillariophyceae berkorelasi kuat dengan suhu, DO, dan $\mathrm{pH}(r>0,6)$. Chlorophyceae memiliki korelasi yang kuat dengan suhu dan $\mathrm{pH}(r>0,69)$. Cyanophyceae dan Dinophyceae memiliki korelasi yang kuat dengan semua nutrien di Waduk Jatigede $(r>0,78)$. Euglenophyceae memiliki korelasi yang kuat dengan nitrit $(r=0,65)$ (Tabel 4).

Korelasi fitoplankton dengan nutrien dan kualitas digambarkan melalui grafik biplot. Komunitas fitoplankton diwakili oleh kelimpahan per kelas fitoplankton. Berdasarkan grafik biplot terlihat komponen pertama merupakan kelas Cyanophyceae dan Dinophyceae dengan fosfor, amonium, dan nitrat. Komponen utama yang kedua adalah komponen Chlorophyceae, Bacialliarophyceae, dan suhu. Komponen ketiga adalah nitrit dan Euglenophyceae (Gambar 5).
Kelimpahan fitoplankton memiliki tren yang sama dengan konsentrasi nutrien bahwa konsentrasi dan kelimpahan menurun dari bagian riverin ke lakustrin. Komposisi fitoplankton di Waduk Jatigede berbeda di setiap bagiannya. Bagian riverin dan transisi memiliki dominasi Cyanophyceae. Menurut Retnaningdyah et al. (2010) Cyanophyceae dari jenis Microcystis mencapai kelimpahan maksimum pada konsentrasi nitrat 8-64 mg/L dengan konsentrasi fosfor 0,4 mg/L. Pernyataan ini menguatkan kondisi nutrien yang tinggi sejalan dengan kelimpahan Cyanophyceae yang tinggi. Korelasi Cyanophyceae dan nutrien juga menunjukkan adanya hubungan kuat dengan koefisien korelasi > 0,90.

Chlorophyceae mendominasi di bagian lakustrin dengan proporsi sebesar 42,23\% dari keseluruhan kelimpahan fitoplankton di bagian tersebut. Kondisi nutrien pada bagian lakustrin berbeda dari bagian riverin dan transisi, yakni konsentrasi yang rendah pada nitrat, nitrit, dan amonium. Perbedaan dominasi kelas fitoplankton dan nutrien ini menunjukkan bahwa setiap kelas fitoplankton memiliki karateristik yang berbeda. Wetzel (2001) menyatakan bahwa pengayaan nutrien dan karakteristik perairan berpengaruh pada fitoplankton yang mendominasi. Dominasi Chlorophyceae menunjukkan kondisi perairan yang oligotrofik, sebaliknya dominasi Cyanophyceae menunjukkan perairan yang eutrofik. Kondisi zona lakustrin di Waduk Jatigede masih tergolong oligotrofik jika dilihat dari dominasi Chlorophyceae.

Diversitas fitoplankton ditunjukkan dengan indeks diversitas Shannon-Wiener. Jorgensen et al. (2005) menyatakan bahwa indeks diversitas yang berkisar antara 1-2 menggambarkan keanekaragaman yang cenderung buruk dan indeks 2-3 menggambarkan status keanekaragaman sedang. Berdasarkan pernyataan tersebut dapat disimpulkan bahwa keanekaragaman fitoplankton Waduk Jatigede cenderung kurang beragam. Indeks diversitas fitoplankton menurun dari bagian riverin ke bagian lakustrin. Indeks diversitas fitoplankton yang tinggi di bagian riverin menunjukkan keanekaragaman yang tinggi di bagian tersebut, sebaliknya indeks diversitas di bagian lakustrin yang terendah menunjukkan komunitas

Tabel 6 Parameter kualitas air Waduk Jatigede

\begin{tabular}{lccc}
\hline $\begin{array}{c}\text { Bagian } \\
\text { danau }\end{array}$ & $\mathrm{DO}(\mathrm{mg} / \mathrm{L})$ & $\mathrm{pH}$ & Suhu $\left({ }^{\circ} \mathrm{C}\right)$ \\
\hline Riverin & $7,210 \pm 0,41$ & $7,346 \pm 0,10$ & $26,583 \pm 0,17$ \\
Transisi & $7,417 \pm 0,19$ & $7,353 \pm 0,06$ & $26,536 \pm 0,23$ \\
Lakustrin & $7,646 \pm 0,13$ & $7,506 \pm 0,06$ & $26,594 \pm 0,10$ \\
\hline
\end{tabular}

Tabel 7 Korelasi pearson antara kelimpahan fitoplankton, nutrien, dan kualitas air

\begin{tabular}{lrrrrrrrr}
\hline Kelas Fitoplankton & \multicolumn{1}{c}{ Fosfor } & \multicolumn{1}{c}{ Suhu } & DO & \multicolumn{1}{c}{ pH } & Nitrat & Nitrit & Amonium \\
\hline Bacillariophyceae & $-0,23$ & 0,85 & & 0,69 & 0,94 & $-0,78$ & $-0,98$ & $-0,63$ \\
Chlorophyceae & 0,22 & 0,99 & 0,30 & 0,69 & $-0,42$ & $-0,81$ & $-0,22$ \\
Cyanophyceae & 0,90 & $-0,57$ & $-0,97$ & $-0,88$ & 0,99 & 0,92 & 0,95 \\
Dinophyceae & 0,78 & $-0,74$ & $-0,89$ & $-0,96$ & 0,95 & 0,98 & 0,86 \\
Euglenophyceae & $-0,44$ & $-0,96$ & $-0,06$ & $-0,72$ & 0,19 & 0,65 & $-0,01$ \\
\hline
\end{tabular}




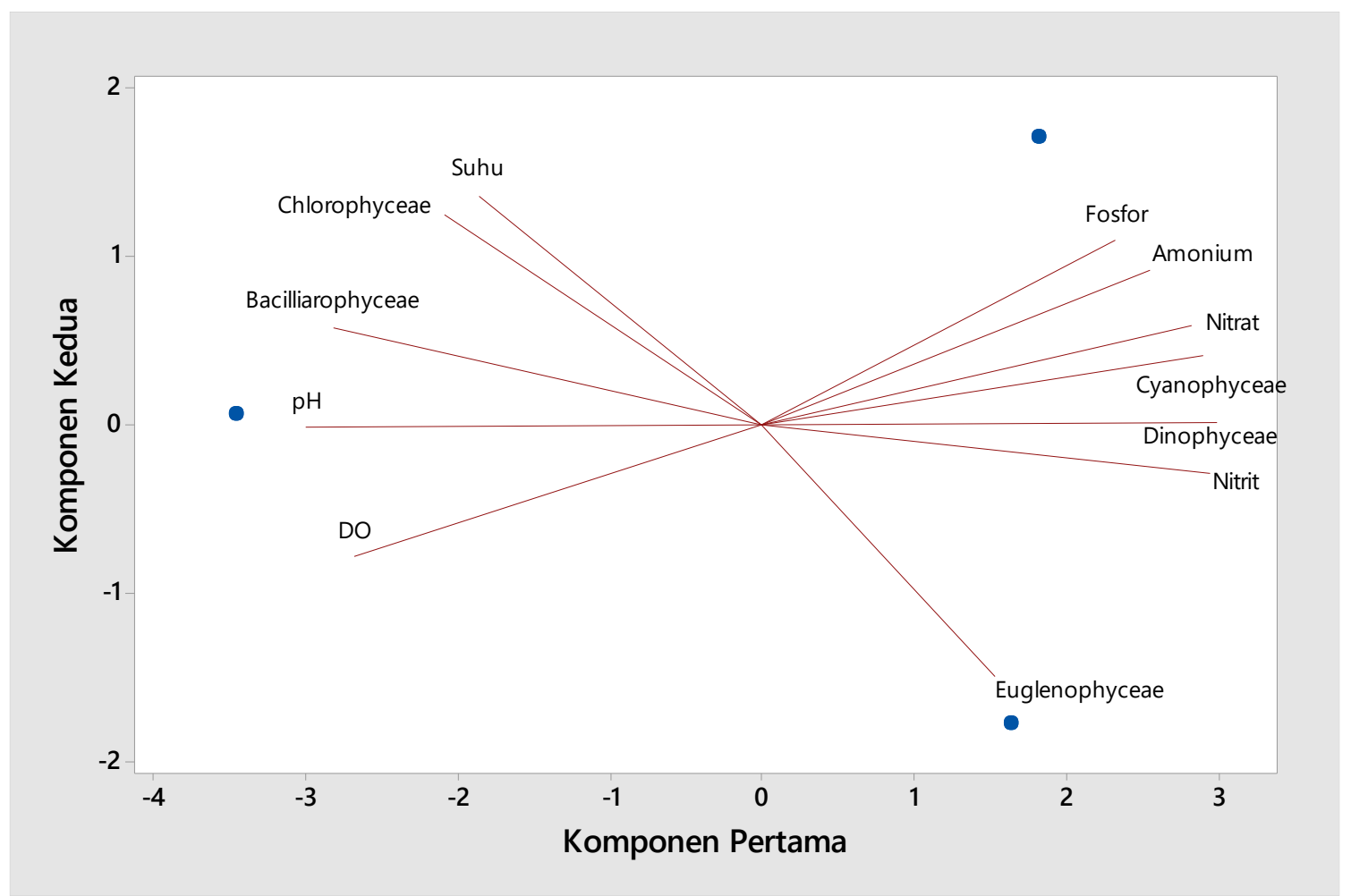

Gambar 5 Biplot komponen utama fisik (DO, pH, dan suhu), kimia (fosfat, amonium, nitrit, dan nitrat), dan biologi (plankton) di Waduk Jatigede, Jawa Barat.

fitoplankton yang cenderung homogen. Indeks dominansi meningkat dari bagian riverin ke bagian lakustrin. Dominansi terlihat pada komposisi fitoplankton, bagian riverin memiliki proporsi yang tidak terlalu tinggi antarkelas fitoplankton, sebaliknya di bagian lakustrin proporsi Chlorophyceae sangat tinggi. Pola diversitas fitoplankton di Waduk Darma menurut Hasan et al. (2017) menunjukkan penurunan indeks diversitas fitoplankton dari bagian inlet waduk dengan indeks 1,298-1,376 dan bagian outlet dengan indeks $0,726-1,166$.

Bacillariophyceae dan Cyanophyceae memiliki korelasi yang kuat dengan suhu $(r>0,85)$. Suhu ratarata selama penelitian berkisar antara 26,536$26,594^{\circ} \mathrm{C}$. Berdasarkan analisis komponen utama Bacillariophyceae, Chlorophyceae, dan suhu merupakan satu komponen yang sama. Hasil analisis korelasi Pearson dan analisis komponen utama menunjukkan bahwa keberadaan Bacillariophyceae dan Chlorophyceae memiliki kaitan yang erat dengan suhu. Hardiyanto et al. (2012) menyatakan bahwa Bacillariophyceae di Waduk Saguling tumbuh subur pada suhu $22,6-27,6^{\circ} \mathrm{C}$. Pernyataan ini diperkuat oleh Litchman (2010) bahwa Bacillariophyceae muncul di perairan bersuhu sedang dengan kisaran suhu 25$35^{\circ} \mathrm{C}$.

Rahman et al. (2016) menyatakan bahwa produktivitas fitoplankton memiliki korelasi dengan konsentrasi nutrien $(r=0,635)$. Kaitan nutrien dengan fitoplankton terlihat dari korelasi Cyanophyceae dengan nutrien $(r>0,90)$. Lv et al. (2011) melaporkan hal yang sama bahwa Cyanophyceae memiliki korelasi dengan nutrien, terutama fosfor. Korelasi ini terjadi karena Cyanophyceae memiliki kemampuan untuk menyimpan fosfor dan memfiksasi nitrogen dari atmosfer (Rakocevic 2012). Edwards et al. (2012) menyatakan bahwa Cyanophyceae memanfaatkan fosfat lebih baik daripada kelas fitoplankton yang lainnya.

Dinophyceae memiliki korelasi yang kuat dengan semua nutrien, terutama dengan nitrat dan nitrit $(r>0,90)$. Domingues et al. (2011) menyatakan bahwa Dinophyceae mencapai laju pertumbuhan yang tinggi pada kondisi perairan yang kaya nitrat. Hal yang sama juga dinyatakan oleh Baek et al. (2008) bahwa pertumbuhan Dinophyceae dari genus Ceratium dipengaruhi oleh nitrat dibandingkan fosfor. Pengaruh nitrat juga terlihat pada bagian riverin Waduk Jatigede bahwa kelimpahan Dinophyceae tertinggi terletak pada konsentrasi nitrat yang tinggi pula.

Analisis komponen utama dan korelasi Pearson menunjukkan adanya hubungan komunitas fitoplankton dengan nutrien yang berada di perairan. Nutrien dimanfaatkan oleh fitoplankton untuk mendukung pertumbuhannya (Baird et al. 2001; Rattan et al 2012). Cyanophyceae dan Dinophyceae merupakan kelas yang memiliki hubungan kuat dengan nutrien, sedangkan Chlorophyceae dan Bacilliarophyceae memiliki hubungan negatif dengan nutrien. Setiap jenis fitoplankton memiliki kemampuan berbeda dalam pemanfaatan nutrien (Lichtman et al. 2007). 


\section{KESIMPULAN}

Konsentrasi nutrien di Waduk Jatigede cenderung mengalami penurunan dari zona riverin menuju lakustrin. Konsentrasi nutrien yang berbeda menyebabkan perbedaan dominasi fitoplankton. Zona riverin dan transisi didominasi oleh Cyanophyceae, sedangkan zona lakustrin didominasi oleh Chlorophyceae. Cyanophyceae dan Dinophyceae memiliki korelasi yang kuat dengan konsentrasi nutrien di Waduk Jatigede. Penyebab terjadinya korelasi yang kuat antara Cyanophyceae dan Dinophyceae dan nutrien adalah kebutuhan tinggi fitoplankton tersebut dalam pemanfaatan nutrien bagi pertumbuhannya.

\section{DAFTAR PUSTAKA}

Abubakar A. dan Abdullahi BA. 2015. Flora composition of phytoplankton as bioindicators of water quality in jakara dam, kano state, Nigeria. Bayero Journal of Pure and Applied Sciences. 8(2): 145-155. https://doi.org/10.4314/bajopas.v8i2.25

American Public Health Association. 2012. Standard Methods for Examination of Water and Wastewater. 22nd ed. American Public Health Association, Water Environment Federation, Washington (USA).

Baek SH, Shimode S, Han MS, Kikuchi T. 2008. Growth of dinoflagellates, Ceratium furca and Ceratium fusus in Sagami Bay, Japan: The role of nutrientnutrients. Harmful Algae. 7: 729-739. https://doi.org/10.1016/j.hal.2008.02.007

Baird ME, Emsley SM, McGlade JM. 2001. Modelling the interacting effects of nutrients uptake, light capture and temperature on phytoplankton growth. Journal of Plankton Research. 23(8): 829-840. https://doi.org/10.1093/plankt/23.8.829

Domingues RB, Barbosa AB, Sommer U, Galvão HM. 2011. Ammonium, nitrate and phytoplankton interactions in a freshwater tidal estuarine zone: potential effects of cultural eutrophication. Aquatic Science. 73: 331-343. https://doi.org/10.1007/ s00027-011-0180-0

Edwards KF, Thomas MK, Klausmeier,CA dan Litchman E. 2012. Allometric scaling and taxonomic variation in nutrient utilization traits and maximum growth rate of phytoplankton. Limnology and Oceanography. 57(2), 554-566. https://doi.org/ 10.4319/lo.2012.57.2.0554

Hardiyanto R, Suherman H, Pratama RI. 2012. Kajian Produktivitas Primer fitoplankton di Waduk Saguling, Desa Bongas dalam kaitannya dengan kegiatan perikanan. Jurnal Perikanan dan Kelautan. 3(4): 51-59

Hasan ODS, Dinno S, Sopiyan D, Endang S, lin SD. 2017. Diversitas plankton dan kualitas perairan
Waduk Darma Kabupaten Kuningan Jawa Barat. Jurnal Penyuluhan Perikanan dan Kelautan. 11(3): 144-159. https://doi.org/10.33378/jppik.v11i3.92

Jiao Y, Chen Y, He W, Liu WX, Xu FU. 2018. The spatial distribution of phosphorus and their correlations in surface sediments and pore water in Lake Chaohu, China. Environmental Science and Pollution Research. 25: 25906. https://doi.org/ 10.1007/s11356-018-2606-x

Jørgensen SE, Costanza R, Xu FL. 2005. Handbook of ecological indicators for assessment of ecosystem health. Boca Raton (US): CRC Press https:// doi.org/10.1201/9780203490181

Krebs CJ. 2014. Ecology: The Experimental Analysis of Distribution and Abundance. 6th ed. London (GB). Pearson.

Kusumaningtyas DI. 2010. Analisis Kadar Nitrat dan Klasifikasi Tingkat Kesuburan di Perairan Waduk Ir. H. Djuanda, Jatiluhur, Purwakarta. Buletin Teknik Litkayasa. 8(2): 49-54.

Le TTH, Fettig J, Meon G. 2018. Kinetics and simulation of nitrification at various $\mathrm{pH}$ values of a polluted river in the tropics. Ecohydrology and Hydrobiology. 19(1): 54-65. https://doi.org/ 10.1016/j.ecohyd.2018.06.006

Legendre P, Legendre L. 1998. Numerical Ecology. Amsterdam (NL): Elsevier.

Litchman E, Pinto PDT, Klausmeier CA, Thomas MK, Yoshiyama K. 2010. Linking traits to species diversity and community structure in phytoplankton. Hydrobiologia, 653: 15-28. https://doi.org/ 10.1007/s10750-010-0341-5

Lv J, Wu H dan Chen M. 2011. Effects of nitrogen and phosphorus on phytoplankton composition and biomass in 15 subtropical, urban shallow lakes in Wuhan, China. Limnologica. 41: 48-56. https:// doi.org/10.1016/j.limno.2010.03.003

McCormick PV. dan Cairns J. 1994. Algae as indicators of environmental change. Journal of Applied Phycology. 6: 509-526. https://doi.org/ 10.1007/BF02182405

Mizuno T. 1979. Illustrations of The Freshwater Plankton of Japan. Osaka (JP): Hoikusha Publishing Co.

Pratiwi NTM, Hariyadi S, Ayu IP, Iswantari A, dan Amalia FJ. 2013. Komposisi Fitoplanton dan Status Kesuburan Perairan Danau Lido, Bogor-Jawa Barat Melalui Beberapa Pendekatan. Jurnal Biologi Indonesia. 9(1): 111-120.

Rahman EC, Masyamsir, Rizal A. 2016. Kajian Variabel Kualitas Air Dan Hubungannya Dengan Produktivitas Primer Fitoplankton Di Perairan Waduk Darma Jawa Barat. Jurnal Perikanan Kelautan. 7(1): 93-102. 
Rakocevic J. 2012. Spatial and temporal diStribution of phytoplankton in lake Skadar. Archives of Biological Sciences. 64(2): 585-595. https://doi.org/ 10.2298/ABS1202585R

Rattan KJ, Taylor WD dan Smith REH. 2012. Nutrient status of phytoplankton across a trophic gradient in Lake Erie: evidence from new fluorescence methods. Canadian Journal of Fisheries and Aquatic Sciences. 69(1): 94-111. https://doi.org/ 10.1139/£2011-135

Retnaningdyah C, Suharjono, Agoes S, Bambang I. 2010. Daya Dukung dan Laju Pertumbuhan Microcystis Hasil Isolasi dari Waduk Sutami pada Berbagai Variasi Konsentrasi Nitrat dan Fosfat dalam Medium Selektif B-12. Biota. 15(3): 354-362.

Rhee GY, Ivan JG. 1980. Optimum N:P ratio and coexistence of planktonic algae. Journal of Phycology. 16: 486-489. https://doi.org/ 10.1111/j.1529-8817.1980.tb03065.x

Singh UB, Ahluwalia AS, Sharma C, Jindal R, Thakur RK. 2013. Planktonic indicators: A promising tool for monitoring water quality (early-warning signals). Ecology, Environment and Conservation. 19(3): 793-800.

Soares MCS, Marinho MM, Huszar VLM, Branco CWC dan Azevedo SMFO. 2008. The effects of water retention time and watershed features on the limnology of two tropical reservoirs in Brazil. Lakes
\& Reservoirs: Research and Management. 13: 257269. https://doi.org/10.1111/j.1440-1770.2008. 00379.x

Steinman A, Chu X, Ogdahl M. 2009. Spatial and temporal variability of internal and external phosphorus loads in Mona Lake, Michigan. Aquatic Ecology. 43: 1-18. https://doi.org/10.1007/s10452007-9147-6

Thakur RK, Jindal R, Singh UB. 2013. Plankton diversity and water quality assessment of three freshwater lakes of Mandi (Himachal Pradesh, India) with special reference to planktonic indicators. Environmental Monitoring and Assessment. 185: 8355-8373. https://doi.org/ 10.1007/ s10661-013-3178-3

Tillman, David., S.S. Kilham, P. Kilham. 1982. Phytoplankton Community Ecology: The role of limiting nutrientnutrients. Annual Review of Ecology and Systematics. 13: 349-372. https://doi.org/ 10.1146/annurev.es.13.110182.002025

Warsa A. 2016. Model perencanaan pengelolaan dan optimalisasi waduk berbasis perikanan jaring apung dan perikanan alami (Studi Kasus: Waduk Jatigede, Sumedang-Jawa Barat). [Tesis]. Bogor (ID): Institut Pertanian Bogor.

Wetzel RG. 2001. Limnology. 3rd Ed. California (US): Academic Press. 